Check for updates

Cite this: RSC Adv., 2017, 7, 34236

Received 5th February 2017

Accepted 4th May 2017

DOI: $10.1039 / \mathrm{c} 7 \mathrm{ra01476g}$

rsc.li/rsc-advances

\section{Bioassay-guided isolation of bisepoxylignans from the flower buds of Magnolia biondii Pamp and their antiallergic effects $\dagger$}

\author{
Xing Zhang, (D) $\ddagger^{a}$ Fei Qian, $\stackrel{\ddagger}{a}^{a}$ Jun-Jie Tan, ${ }^{a}$ Fu-Jiang Guo, ${ }^{a}$ Marianna Kulka, ${ }^{b}$ \\ Jin-Wen $\mathrm{Xu}^{* \mathrm{*}}$ and Yi-Ming Li ${ }^{\star a}$
}

The dried flower buds of Magnolia biondii Pamp (herbal name, Xin-Yi) are a traditional Chinese medicine with a long history of clinical use in the treatment of allergic rhinitis and sinusitis. However, the constituents responsible for its antiallergic effects remain unidentified. In the present study, a novel bisepoxylignan, isoeudesmin (1), and eight known bisepoxylignans, pluviatilol (2), eudesmin (3), magnolin (4), lirioresinol-B dimethyl ether (5), epimagnolin B (6), kobusin (7), aschantin (8), fargesin (9), were isolated from effective fractions through antiallergic bioassay-guided procedures using mouse bone marrow-derived mast cells (BMMCs) and lgE-induced passive cutaneous anaphylaxis mice. The compound structures were elucidated through nuclear magnetic resonance and mass spectrometry analyses. Compound 1 and compounds 2-6 and 9 exhibited antiallergic effects without affecting the viability of BMMCs. Compounds 2 and 9 showed the strongest effects with $I C_{50}$ values of 52.18 and $93.03 \mu \mathrm{M}$, respectively. In this paper, the structure-activity relationship between these bisepoxylignans and their antiallergic effects is discussed. After evaluating the intensity of the antiallergic effects of the extracts, further separating the fractions, and isolating the purified compounds, we concluded that biosepoxylignans are the main constituents in Xin-Yi contributing to its anti-allergic efficacy.

\section{Introduction}

Magnolia biondii Pamp of the family Magnoliaceae is mainly distributed in Henan, China. ${ }^{1}$ The dried flower buds of Magnolia biondii Pamp (herbal name, Xin-Yi) are among the most commonly used herbs in Chinese medicine. They have a long history of clinical use in the treatment of allergic diseases. ${ }^{2,3}$ In ancient China, Xin-Yi was reported to be efficacious in the treatment of cutaneous pruritus (recorded in the book Solar Corona Medicine, published in 900 A.D.), allergic rhinitis, and sinusitis (recorded in the book Austroyunnanese Medicine, published in 1300 A.D.). The antiallergic effects of Xin-Yi have also been reported in some prescriptions in ancient China. For example, Xanthium pulvis, XinQin decoction, and Xin-Yi decoction, which are mainly composed of Xin-Yi, were used in the treatment of allergic rhinitis, sinusitis, and asthma. These prescriptions are

${ }^{a}$ School of Pharmacy, Shanghai University of Traditional Chinese Medicine, 1200 Cailun Road, Shanghai 201203, China.E-mail: ymli@shutcm.edu.cn

${ }^{b}$ National Institute for Nanotechnology, 11421 Saskatchewan, Edmonton, T6G 2M9, $A B$, Canada

'Institute of Interdisciplinary Research Complex, Shanghai University of Traditional Chinese Medicine, 1200 Cailun Road, Shanghai 201203, China. E-mail:jwxu1001@ 163.com

† Electronic supplementary information (ESI) available: Spectra of all compounds. See DOI: 10.1039/c7ra01476g

\$ These authors contributed equally to this work. still used in clinical medicine today. ${ }^{4}$ Animal experiments have confirmed that these prescriptions exert their antiallergic effects by inhibiting the degranulation of mast cells, ${ }^{5}$ alleviating homologous passive skin anaphylaxis, and suppressing histamine-induced metatarsal swelling in rats. ${ }^{6,7}$ A clinical study reporting on the effects of Xin-Yi decoction in 40 patients with allergic asthma showed that patients who received the treatment exhibited improved pulmonary function and vital capacity, and their forced expiratory volume $1\left(\mathrm{FEV}_{1}\right)$ and $\mathrm{FEV}_{1} \%$ were more significantly altered $(P<0.01)$ than those in a group of controls, indicating that Xin-Yi is highly effective in the treatment of allergies. ${ }^{8}$ Therefore, determining the exact constituents responsible for its antiallergic effects requires additional research.

Phytochemical research has revealed that Xin-Yi is a prolific source of bisepoxylignans, which exhibit a broad range of biological activities, ${ }^{9}$ such as anti-inflammatory, ${ }^{10}$ antioxidant, antimicrobial, anticancer, and antiplatelet activities as well as liver protection. ${ }^{\mathbf{1 1}}$ Recent studies have revealed that various types of lignans, such as gomisin N (dibenzocylooctadiene lignan), mesodihydroguaiaretic acid (dibenzylbutane lignan), and pinusthunbergiside A (benzodioxane lignan), ${ }^{\mathbf{1 2 - 1 4}}$ exert their antiallergic effects by suppressing mast cell activation. Bisepoxylignans from the stems of Lindera obtusiloba Blume were reported to play a crucial role in antiallergic inflammation through the suppression of A23187 - stimulated human mast cell degranulation. ${ }^{15}$ Among a bioactive screen of $95 \%$ ethanol 
(EtOH) extract, water extract, and volatile oil components from Xin-Yi, 95\% EtOH extract was reported to exert the most potent antiallergic effects in vivo; however, the exact constituents contributing to this effect remain unidentified. $^{\mathbf{1 6}}$
Biosepoxylignans are the main constituents of Xin-Yi; therefore, they might play a crucial role in the antiallergic effects of Xin-Yi.

The present study investigated the antiallergic effects of $95 \%$ EtOH extract of Xin-Yi, further separated the fractions, and
A
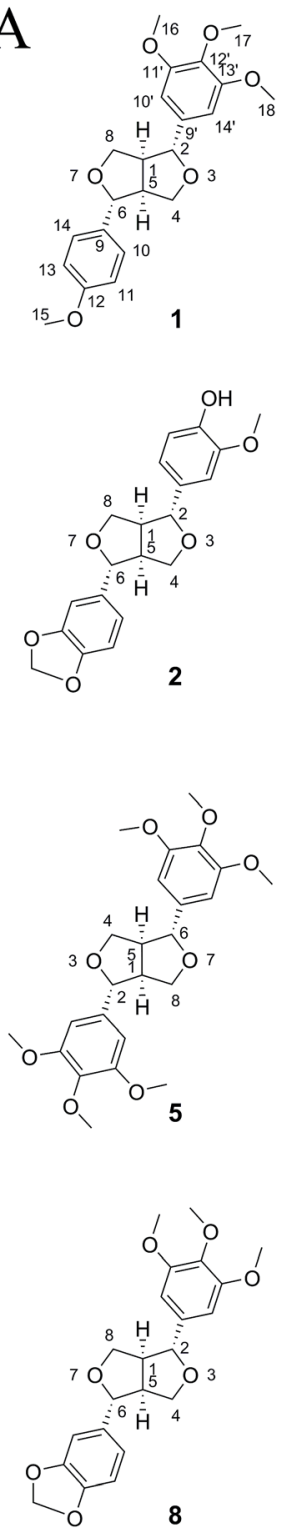

B

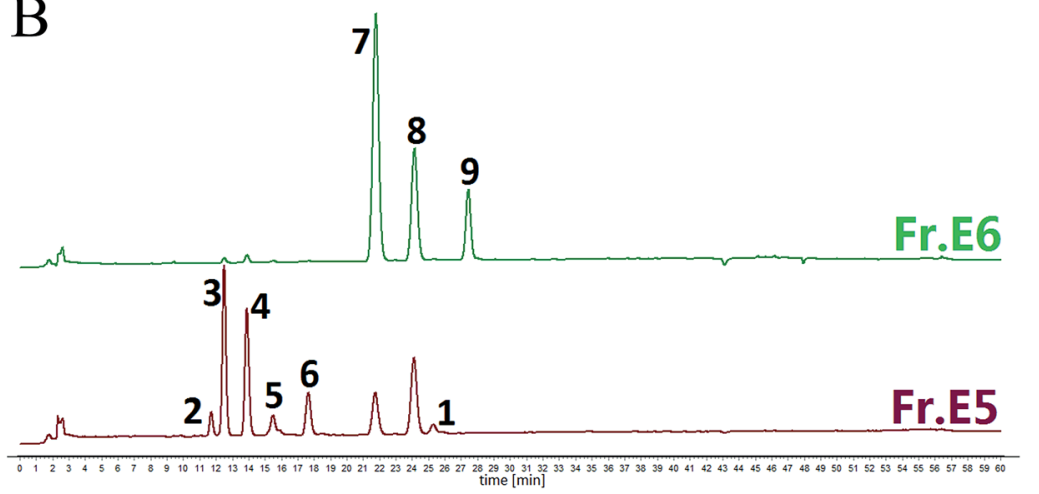

Fig. 1 Chemical structures of nine compounds 1-9 extracted from Xin-Yi (A) and HPLC fingerprints of the effective fractions, Frs. E5 and E6 (B). 
isolated the purified compounds by using an acknowledged antiallergic test model-the mouse bone marrow-derived mast cell (BMMC) degranulation test-and the passive cutaneous anaphylaxis (PCA) mice model. We obtained one novel bisepoxylignan, isoeudesmin (1), and eight known biosepoxylignans, pluviatilol (2), eudesmin (3), magnolin (4), lirioresinol-B dimethyl ether (5), epimagnolin B (6), kobusin (7), aschantin (8), and fargesin (9) (Fig. 1A), through bioassayguided isolation procedures. The bioassay results revealed that compound 1 and compounds 2-6 and $\mathbf{9}$ exerted inhibitory effects on BMMC degranulation and tumour necrosis factor $\alpha$ (TNF- $\alpha$ ) expression. Furthermore, we also discussed the structure-activity relationship between these bisepoxylignans and their antiallergic effects. The results indicated that biosepoxylignans, as the main constituents in Xin-Yi contribute to its antiallergic efficacy.

\section{Experimental section}

\section{General experimental procedures}

IR spectra were obtained using a Nicolet-Magna-750-FTIR spectrometer (KBr pellets) (Thermo Fisher). Optical rotations were recorded using a Perkin-Elmer 341 polarimeter. Silica gel (200-300 mesh; Qingdao Haiyang Chemical Company), Sephadex LH-20 (GE Biosciences), MCI Gel Chp20p (Mitsubishi Chemical, Tokyo, Japan), and ODS (Fuji Silica Chemical Company) were purchased for column chromatography. Thin layer chromatography (TLC) plates were obtained from the Yantai Jiangyou Company. Electron ionisation-mass spectrometry (EI-MS) and high-resolution EI-MS (HR-EI-MS) data were obtained using a Thermo DFS mass spectrometer (in $\mathrm{m} / \mathrm{z}$ ). Electrospray ionisation (ESI)-MS and HR-ESI-MS analyses were performed using a Finnigan LCQ Deca XP equipped with an ESI source mass ion-trap spectrometer and Waters Micromass QTOF Ultima Globe spectrometer, respectively. ${ }^{1} \mathrm{H},{ }^{13} \mathrm{C}$, and ${ }^{2} \mathrm{D}$ nuclear magnetic resonance (NMR) spectra were obtained using Bruker AV-400 and AV-600 instruments. Semipreparative highperformance liquid chromatography (HPLC) was performed using an Agilent 1200 HPLC system, and samples were separated on an Agilent Eclipse $\mathrm{XDB}^{-\mathrm{C}_{18}}(5 \mu \mathrm{m}, 9.4 \times 250 \mathrm{~mm})$ column. The HPLC analysis of effective fractions was performed using an Agilent ZORBAX SB-C ${ }_{18}(5 \mu \mathrm{m}, 4.6 \times 250 \mathrm{~mm})$ column with a mobile phase of $\mathrm{CH}_{3} \mathrm{CN}$ and $\mathrm{H}_{2} \mathrm{O}$ [0-20 min, 40:60 $\left(\mathrm{CH}_{3} \mathrm{CN}: \mathrm{H}_{2} \mathrm{O}\right.$, v/v); 20-40 $\min , 40: 60-60: 40 ; 40-50 \mathrm{~min}$, $60: 40-95: 5$; 50-53 min, $95: 5$; 53-55 min, 95:5-40 : 60; 55$60 \mathrm{~min}, 40: 60$ ] at a flow rate of $1.0 \mathrm{~mL} \mathrm{~min}^{-1}$. UV spectroscopy data were collected at $260 \mathrm{~nm}$.

\section{Plant material}

Xin-Yi was collected from Nanzhao, Henan, China, which is the main Xin-Yi-producing area in China. The authenticity of this medicinal material was verified by Professor Zhili Zhao at the School of Pharmacy, Shanghai University of Traditional Chinese Medicine, Shanghai, China. A voucher specimen (20150101) has been deposited in the Department of Phytochemistry, School of
Pharmacy, Shanghai University of Traditional Chinese Medicine, Shanghai, China.

\section{Extraction and isolation}

Dried and powdered Xin-Yi $(17.5 \mathrm{~kg})$ was extracted three times under reflux conditions in $95 \%$ EtOH $(60 \mathrm{~L}$ and $2 \mathrm{~h}$ each at 80 $\left.{ }^{\circ} \mathrm{C}\right)$. The combined extracts were evaporated at reduced pressure to yield a crude extract in vacuo at $60^{\circ} \mathrm{C}$. The crude extract was suspended in water $(20 \mathrm{~L})$ and subsequently partitioned with petroleum ether $(\mathrm{PE} ; 20 \mathrm{~L} \times 3$ ) and ethyl acetate (EtOAc; $20 \mathrm{~L} \times 3)$ successively. The combined EtOAc extract $(1 \mathrm{~kg})$ was subjected to MCI column chromatography and eluted with EtOH- $\mathrm{H}_{2} \mathrm{O}$ mixtures of decreasing polarity (EtOH : $\mathrm{H}_{2} \mathrm{O}=$ $1: 9,2: 8,4: 6,5: 5,6: 4,7: 3$, and $9: 1$ ) to yield six fractions (Frs. E1-E6) according to the TLC monitor. Frs. E5-E6 exhibited higher antiallergic activity than did Frs. E1-E4; therefore, they were subjected to further purification. Purifying Fr. E5 (24 g) through Sephadex LH-20 chromatography and eluting it with $\mathrm{MeOH}$ yielded compound 3 (117 mg) and six fractions (Frs. E5A-E5F). Purifying Fr. E5B (16 g) through ODS chromatography and eluting it with a $\mathrm{MeOH}-\mathrm{H}_{2} \mathrm{O}$ system afforded compound 5 (529 mg) and six fractions (Frs. E5B1E5B6). A $30 \mathrm{mg}$ quantity of Fr. E5B5 (4.2 g) was purified through semipreparative HPLC in an $\mathrm{ACN}-\mathrm{H}_{2} \mathrm{O}$ system, yielding compounds 4 (16 mg) and 6 ( $8 \mathrm{mg}$ ). Purifying Fr. E5C (2 g) through silica gel chromatography and eluting it with a PE-EtOAc system yielded compound 2 (24 mg). Subjecting Fr. E6 (6 g) to Sephadex LH-20 chromatography and eluting it with $\mathrm{MeOH}$ yielded 10 fractions (Frs. E6A-E6J). Fr. E6D (3 g) was further separated through ODS chromatography, eluted with $\mathrm{MeOH}-\mathrm{H}_{2} \mathrm{O}$, and then subjected to semipreparative HPLC in an ACN- $\mathrm{H}_{2} \mathrm{O}$ system to yield compounds 1 (5 mg), 7 (15 mg), and 8 (21 mg). A $20 \mathrm{mg}$ quantity of Fr. E6F (1 g) was purified through semipreparative HPLC in $\mathrm{ACN}-\mathrm{H}_{2} \mathrm{O}$ system to obtain compound 9 (6 mg).

Isoeudesmin (1). Yellowish wax, $[\alpha]_{\mathrm{D}}^{25}:+70(c$ 0.1, MeOH); UV $(\mathrm{MeOH}) \lambda_{\max } \mathrm{nm}: 207,232,273 . \mathrm{IR}(\mathrm{KBr}) \nu_{\max } \mathrm{cm}^{-1}: 1590,1512$, 1462, 1417, 1373, 1329, 1246, 1175, 1128, 1061, 1035, 1007, 825; ${ }^{1} \mathrm{H}-\mathrm{NMR}\left(\mathrm{CDCl}_{3}, 600 \mathrm{MHz}\right)$ and ${ }^{13} \mathrm{C}-\mathrm{NMR}\left(\mathrm{CDCl}_{3}, 151 \mathrm{MHz}\right)$ NMR data (Table 1); HR-EI-MS at $m / z: 386.1725[\mathrm{M}]^{+}$(calculated for $\mathrm{C}_{22} \mathrm{H}_{26} \mathrm{O}_{6}, 386.1729$ ).

\section{BMMC culture}

BMMCs were derived from the bone marrow of BALB/c mice. Cells were maintained in RPMI-1640 medium (Gibco) supplemented with $50 \mu \mathrm{M}$ 2-mercaptoethanol (Sigma-Aldrich), $1 \mathrm{mM}$ sodium pyruvate, $100 \mathrm{U}$ per $\mathrm{mL}$ penicillin/100 $\mu \mathrm{g} \mathrm{mL}^{-1}$ streptomycin, $0.1 \mathrm{mM}$ nonessential amino acids, $25 \mathrm{mM} \mathrm{N}-2$ hydroxyethylpiperazine- $N$-2'-ethanesulfonic acid (HEPES), 10\% foetal bovine serum, and $10 \mathrm{ng} \mathrm{mL}^{-1}$ mouse recombinant interleukin-3 (PeproTech, Rocky Hill, NJ, USA). Cells were fed every 5 days. After 4 weeks, cell purity was assessed by measuring CD117 and FceRI expression levels though flow cytometry. Of the cells, 99\% were double-positive for CD117 and FceRI. 
Table $1{ }^{1} \mathrm{H}-\mathrm{NMR}(600 \mathrm{MHz})$ and ${ }^{13} \mathrm{C}-\mathrm{NMR}(151 \mathrm{MHz})$ spectral data of compound (1) in $\mathrm{CDCl}_{3}$

\begin{tabular}{|c|c|c|}
\hline & ${ }^{1} \mathrm{H}$ & ${ }^{13} \mathrm{C}$ \\
\hline Position & $\delta_{\mathrm{H}}($ multiplicity, $J$ in $\mathrm{Hz})$ & $\delta_{\mathrm{C}}$,type \\
\hline 1 & $3.07(\mathrm{~m})$ & $54.63 \mathrm{CH}$ \\
\hline 2 & $4.73(\mathrm{~d}, 5.0)$ & $86.24 \mathrm{CH}$ \\
\hline 4 & $4.29(\mathrm{dd}, 9.1,6.8), 3.88-3.94(\mathrm{~m})$ & $72.21 \mathrm{CH}_{2}$ \\
\hline 5 & $3.11(\mathrm{~m})$ & $54.16 \mathrm{CH}$ \\
\hline 6 & $4.78(\mathrm{~d}, 4.7)$ & $85.66 \mathrm{CH}$ \\
\hline 8 & $4.25(\mathrm{dd}, 9.2,6.6), 3.88-3.94(\mathrm{~m})$ & $71.71 \mathrm{CH}_{2}$ \\
\hline 9 & - & $133.11 \mathrm{C}$ \\
\hline $9^{\prime}$ & - & $136.99 \mathrm{C}$ \\
\hline 10 & $7.28(\mathrm{~d}, 8.6)$ & $127.47 \mathrm{CH}$ \\
\hline $10^{\prime}$ & $6.57(\mathrm{~s})$ & $102.91 \mathrm{CH}$ \\
\hline 11 & $6.89(\mathrm{~d}, 8.6)$ & $114.10 \mathrm{CH}$ \\
\hline $11^{\prime}$ & - & $153.56 \mathrm{C}$ \\
\hline 12 & - & $159.35 \mathrm{C}$ \\
\hline $12^{\prime}$ & - & $137.55 \mathrm{C}$ \\
\hline 13 & $6.89(\mathrm{~d}, 8.6)$ & $114.10 \mathrm{CH}$ \\
\hline $13^{\prime}$ & - & $153.56 \mathrm{C}$ \\
\hline 14 & $7.28(\mathrm{~d}, 8.6)$ & $127.47 \mathrm{CH}$ \\
\hline $14^{\prime}$ & $6.57(\mathrm{~s})$ & $102.91 \mathrm{CH}$ \\
\hline 15 & $3.84(\mathrm{~s})$ & $55.45 \mathrm{CH}_{3}$ \\
\hline 16 & $3.87(\mathrm{~s})$ & $56.31 \mathrm{CH}_{3}$ \\
\hline 17 & $3.81(\mathrm{~s})$ & $60.99 \mathrm{CH}_{3}$ \\
\hline 18 & $3.87(\mathrm{~s})$ & $56.31 \mathrm{CH}_{3}$ \\
\hline
\end{tabular}

\section{Cell viability analysis using XTT assay}

BMMCs were dispensed into 96-well plates $\left(5 \times 10^{4}\right.$ cells per well) and treated with the isolated compounds $(100 \mu \mathrm{M})$ for $24 \mathrm{~h}$, and cell viability was assessed using a 2.3-bis-(2-methoxy4-nitro-5-sulfophenyl)-2 $H$-tetrazolium-5-carboxyanilide salt (XTT)-based cell proliferation assay (Life Technologies, Mannheim, Germany), following the manufacturer's instructions. Cell viability is expressed as the percentage of $\mathrm{OD}_{\text {test }}$ relative to $\mathrm{OD}_{\text {control }}$, where $\mathrm{OD}_{\text {test }}$ is the optical density of cells exposed to compounds (test samples), and $\mathrm{OD}_{\text {control }}$ is the optical density of the control samples.

\section{Degranulation assay}

First, BMMCs at $5 \times 10^{5}$ cells per mL were incubated with $0.5 \mu \mathrm{g}$ $\mathrm{mL}^{-1}$ antidinitrophenol-IgE (anti-DNP-IgE) (Sigma Aldrich) in complete media overnight for sensitisation. Cells were resuspended in HEPES buffer (10 mM HEPES, $137 \mathrm{mM} \mathrm{NaCl}, 2.7 \mathrm{mM}$ $\mathrm{KCl}, 0.4 \mathrm{mM} \mathrm{Na}_{2} \mathrm{HPO}_{4} \cdot 7 \mathrm{H}_{2} \mathrm{O}, 5.6 \mathrm{mM}$ glucose, $1.8 \mathrm{mM} \mathrm{CaCl}_{2}-$ $\cdot 2 \mathrm{H}_{2} \mathrm{O}$, and $1.3 \mathrm{mM} \mathrm{MgSO}{ }_{4} \cdot 7 \mathrm{H}_{2} \mathrm{O}$ ) and transferred to a roundbottom 96-well plate. Subsequently, cells were treated with extracts $\left(50 \mathrm{mg} \mathrm{L}^{-1}\right)$ or compounds $(25,50$, or $100 \mu \mathrm{M})$ for $30 \mathrm{~min}$. Finally, cells were stimulated with $0.1 \mu \mathrm{g} \mathrm{mL} \mathrm{m}^{-1}$ DNPbovine serum albumin (DNP-BSA; Biosearch Technologies) for $30 \mathrm{~min}$. After sensitisation and stimulation, BMMC degranulation was assessed by measuring the $\beta$-hexosaminidase ( $\beta$-hex) release. The $\beta$-hex concentration in the supernatants and pellets was quantified through $p$-nitrophenyl $N$-acetyl- $\beta$-D-glucosamide (Sigma-Aldrich, St. Louis, MO, USA) hydrolysis in $0.1 \mathrm{M}$ sodium citrate buffer (pH 4.5) for 90 min at $37^{\circ} \mathrm{C}$. After 50 glycine (pH
10.7, Amresco) was added to each fraction, the absorbance was measured at $A_{405}$ and $A_{570}$ using a Multiskan Ascent 354 microplate reader (Thermo Labsystems, Vantaa, Finland). The amount of total $\beta$-hex released was calculated using the following formula: $\%$ release $=100 \times$ supernatant absorbance/ (supernatant absorbance + pellet absorbance).

\section{Cytokine enzyme-linked immunosorbent assay}

BMMCs were dispensed into 48 -well plates $\left(1 \times 10^{5}\right.$ cells per well) and sensitised with $0.5 \mu \mathrm{g} \mathrm{mL}{ }^{-1}$ anti-DNP-IgE for $24 \mathrm{~h}$. The isolated compounds were dissolved in media containing $0.1 \%$ dimethyl sulfoxide and added to the cells to obtain a final concentration of $100 \mu \mathrm{M}$ for $30 \mathrm{~min}$. Cells were stimulated with DNP-BSA for $24 \mathrm{~h}$ for TNF- $\alpha$ expression. The supernatant was collected, centrifuged at $300 \times g$ for 5 min to remove any cell debris, and stored at $-80{ }^{\circ} \mathrm{C}$ until ELISA analysis. The supernatant was analysed for TNF- $\alpha$ expression using ELISA kits (eBioscience), following the manufacturer's instructions.

\section{IgE-mediated local anaphylaxis in mice}

ICR mice ( 6 week-old, male, 20-22 g) were obtained from the B\&K Laboratory Animal Corp. Ltd. (Shanghai, China). All animal experiments were performed according to the Health Guidelines of the Shanghai University of Traditional Chinese Medicine, China, and protocols were approved by the Institutional Animal Ethics Committee of Shanghai University of Traditional Chinese Medicine. All mice were kept under a 12 hour light-dark cycle, temperature of $22{ }^{\circ} \mathrm{C}$ to $23{ }^{\circ} \mathrm{C}$, and humidity of $50 \%$ to $60 \%$. The animals were allowed free access to food and water and allowed to acclimatize for at least 7 days before the experiments.

IgE-induced PCA was performed as described previously. ${ }^{17}$ Briefly, $1 \mu \mathrm{g}$ anti-DNP-IgE was intradermally injected into the right ear of 7 week old male mice. The next day, the mice received oral administration of $100 \mathrm{mg} \mathrm{kg}^{-1}$ Frs. E5 and E6 (in that order) or $50 \mathrm{mg} \mathrm{kg}^{-1}$ Ketotifen fumarate salt (SigmaAldrich). After 1 hour, the mice were challenged for $30 \mathrm{~min}$ by intravenous injection of $100 \mu \mathrm{g}$ of DNP-HSA in $300 \mu \mathrm{L}$ saline containing Evans blue (0.5\%). Finally, Evans blue was extracted after $24 \mathrm{~h}$ at room temperature with $300 \mu \mathrm{L}$ of formanide and measured by absorbance at $630 \mathrm{~nm}$.

\section{Statistical analysis}

Experiments were conducted in triplicate. Values are presented as the mean \pm standard error of the mean. Significant differences were determined using the Student $t$ test with the level of significance set at ${ }^{*} P \leq 0.05,{ }^{* *} P \leq 0.01$, and ${ }^{* * *} P \leq 0.001$.

\section{Results and discussion}

The EtOAc-soluble portion of the 95\% EtOH extract of Xin-Yi was purified separately by column chromatography over MCI gel, silica gel, reversed-phase $\mathrm{C}_{18}$ silica gel, Sephadex LH-20, and by preparative HPLC, yielding six fractions and nine compounds, including one novel biosepoxylignan (1) and eight known biosepoxylignans (2-8) (see Extraction and isolation). 
According to the effect of $95 \%$ EtOH extract on the allergic mouse model, ${ }^{16}$ we examined the effects of $95 \%$ EtOH extract on BMMC degranulation. The results revealed that 95\% EtOH extract exerted a weak antiallergic effect; it inhibited $\beta$-hex release by $22.77 \%$ relative to that of the control at $50 \mathrm{mg} \mathrm{L}^{-1}$ for $30 \mathrm{~min}$ in the BMMC model. Moreover, we examined the effects of $50 \mathrm{mg} \mathrm{L}^{-1}$ EtOAc and PE extracts from 95\% EtOH extract on BMMC degranulation. The results revealed that treatment of BMMCs with EtOAc extract for 30 min considerably reduced the $\beta$-hex release by up to $51.4 \%$ relative to that of the control, whereas PE extracts slightly inhibited the $\beta$-hex release, reducing it by $13.06 \%$ relative to that of the control. On the basis of these results, we hypothesised that EtOAc extract contains the active constituents. Therefore, we examined the effects of the six fractions from EtOAc extract on BMMC degranulation. Treatment of BMMCs with Frs. E2, E3, E5, and E6 at $50 \mathrm{mg} \mathrm{L}^{-1}$ for 30 min considerably affected the BMMC $\beta$-hex release (Fig. 2). In particular, Frs. E5 and E6 inhibited $\beta$-hex release by up to $65.5 \%$ and $85.6 \%$ relative to that of the control, respectively.

Based on the in vitro results, we evaluated the antiallergic activity of Frs. E5 and E6 in a PCA model. As shown as Fig. 3, the colour in the ear of Frs. E5 and E6 group became lighter than

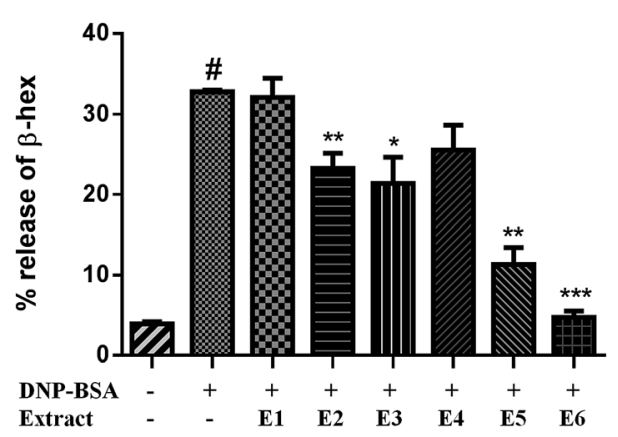

Fig. 2 Effects of fractions from EtOAC extracts on BMMC degranulation. that of the model group. Additionally, Frs. E5 and E6 significantly reduced the dye extravasations by $26.15 \%(P<0.05)$ and $38.94 \%(P<0.001)$, respectively. These results suggest that Frs. E5 and E6 exert in vivo antiallergic effects by suppressing mast cell activation.

Next, nine compounds were obtained from the active Frs. E5, and E6, namely isoeudesmin (1), pluviatilol (2), ${ }^{18}$ eudesmin (3), ${ }^{19}$ magnolin (4), ${ }^{20}$ lirioresinol-B dimethyl ether (5), ${ }^{21}$ epimagnolin B (6), ${ }^{20}$ kobusin (7), ${ }^{20}$ aschantin (8), ${ }^{22}$ and fargesin (9). ${ }^{20}$ Their chemical structures are illustrated in Fig. 1A. Compounds 2-9 were identified by comparing their ${ }^{1} \mathrm{H}-\mathrm{NMR}$ and MS data (details show in the ESI $\dagger$ ) with those reported in the literature. Compound 1 was identified as follows.

Compound 1 was a yellowish wax with a molecular formula of $\mathrm{C}_{22} \mathrm{H}_{26} \mathrm{O}_{6}$, as determined through HR-EI-MS $(\mathrm{m} / \mathrm{z}: 386.1725$ $[\mathrm{M}]^{+}$). The ${ }^{13} \mathrm{C}-\mathrm{NMR}$ and DEPT spectrum (Table 1 ) exhibited four methoxyl signals at $\delta_{\mathrm{C}} 55.45$ (C-15), 56.31 (C-16, 18), and 60.99 (C-17); two methylenes at $\delta_{\mathrm{C}} 71.71$ (C-8) and 72.21 (C-4); two methynes at $\delta_{\mathrm{C}} 54.16(\mathrm{C}-5)$ and $54.63(\mathrm{C}-1)$; two oxygenated methynes at $\delta_{\mathrm{C}} 85.66(\mathrm{C}-6)$ and 86.24 (C-2); three coupled methynes at $\delta_{\mathrm{C}} 102.91\left(\mathrm{C}-10^{\prime}, 14^{\prime}\right), 114.1$ (C-11, 13), and 127.47 $(\mathrm{C}-10,14)$; and six quaternary carbons at $\delta_{\mathrm{C}} 133.11$ (C-9), 136.99 $\left(\mathrm{C}-9^{\prime}\right), 137.55\left(\mathrm{C}-12^{\prime}\right), 153.56\left(\mathrm{C}-11^{\prime}, 13^{\prime}\right)$, and 159.35 (C-12). The ${ }^{1} \mathrm{H}-\mathrm{NMR}$ spectrum (Table 1) revealed four methoxyl signals at $\delta_{\mathrm{H}}$ 3.81 (3H, s, H-17), 3.84 (3H, s, H-15), and 3.87 (6H, s, H-16, 18). The signals of two aromatic protons, including $\delta_{\mathrm{H}} 6.57(\mathrm{~s}, 2 \mathrm{H}, \mathrm{H}-$ $\left.10^{\prime}, 14^{\prime}\right)$, indicated the formation of a 1,3,4,5-tetrasubstituted benzene ring, and the AA'XX'-type aromatic proton signals at $\delta_{\mathrm{H}}$ $6.89(2 \mathrm{H}, \mathrm{d}, J=8.6 \mathrm{~Hz}, \mathrm{H}-11,13)$ and $7.28(2 \mathrm{H}, \mathrm{d}, J=8.6 \mathrm{~Hz}, \mathrm{H}-$ $10,14)$ as well as the signals at $\delta_{\mathrm{H}} 3.07(1 \mathrm{H}, \mathrm{m}, \mathrm{H}-1), 3.11(1 \mathrm{H}, \mathrm{m}$, H-5), 3.88-3.94 (2H, m, H-4a, 8a), 4.25 (1H, dd, $J=9.2,6.6 \mathrm{~Hz}$, $\mathrm{H}-8 \mathrm{e})$, and $4.29(1 \mathrm{H}, \mathrm{dd}, J=9.1,6.8 \mathrm{~Hz}, \mathrm{H}-4 \mathrm{e})$ indicated that compound 1 contains two furan rings. Furthermore, analysis of the HMBC correlations also revealed that there are two furan rings in the compound $1(\delta 4.73 \rightarrow 54.63,71.71,3.88,4.29 \rightarrow$ $54.16,85.66)$, and two benzene rings were linked by these two

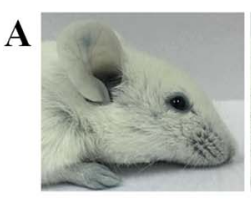

Control

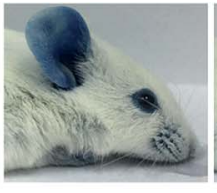

Model

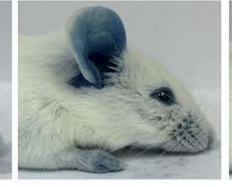

E5

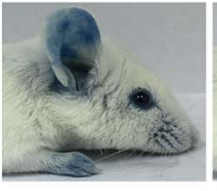

E6

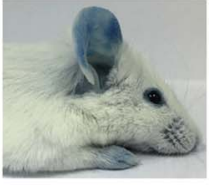

Keto

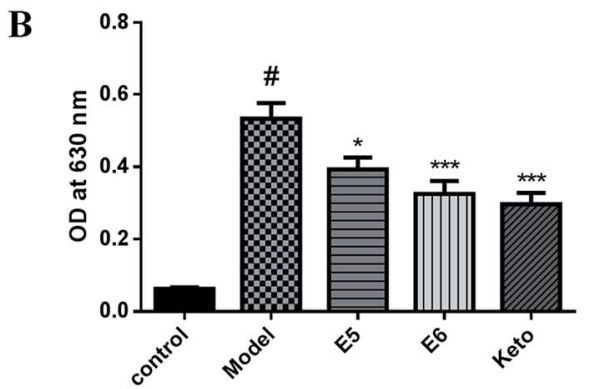

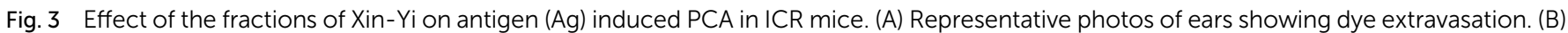
Evans blue dye was extracted in formaldehyde and quantified as absorbance at $630 \mathrm{~nm}$. 
furan rings $(\delta 7.28 \rightarrow 85.66,6.57 \rightarrow 86.24,4.73 \rightarrow 136.99$; Fig. 1A). Therefore, the planar structure of compound 1 was determined. $\mathrm{H}-2=\mathrm{H}-6: \delta$ 4.67-4.78 (d, $J=5 \mathrm{~Hz}), \mathrm{H}-1=\mathrm{H}-5$ : $\delta$ 3.07-3.11, $\mathrm{H}-4 \mathrm{a}=\mathrm{H}-8 \mathrm{a}: \delta$ 3.88-3.94, and $\mathrm{H}-4 \mathrm{e}=\mathrm{H}-8 \mathrm{e}$ : $\delta$ 4.25-4.29 (dd, $J=9.1,6.8 \mathrm{~Hz}$ ) revealed that compound 1 belonged to the symmetrical bisepoxylignan group. ${ }^{23}$ NOSY revealed that $\mathrm{H}-1,5$ and $\mathrm{H}-2,6$ were unrelated and also confirmed that compound 1 was a symmetrical bisepoxylignan (Fig. 1A). Therefore, the absolute configuration of compound 1 was determined, and it was named "isoeudesmin".

Next, the antiallergic effects of compounds 1-9 obtained from Frs. E5 and E6 extracts on BMMC degranulation were evaluated. Results revealed that compounds 1-6 and 9 at 100 $\mu \mathrm{M}$ reduced the $\beta$-hex release without affecting the BMMC viability (Fig. 4A). In addition, treatment of BMMCs with compounds 2 and 9 for 30 min suppressed the $\beta$-hex release in a dose-dependent manner; the inhibition was up to $67.8 \%$ and $46.5 \%$ relative to the control, respectively (Fig. 4B). Furthermore, compounds 2 and 9 were the most effective one, with $\mathrm{IC}_{50}$ values of 52.18 and $93.03 \mu \mathrm{M}$, respectively.

TNF- $\alpha$, produced by activated BMMCs, mediates many physiological processes of allergic inflammation; therefore, we determined the effect of isolated compounds on TNF- $\alpha$ expression. We incubated BMMCs with $0.5 \mu \mathrm{g} \mathrm{mL} \mathrm{m}^{-1}$ anti-DNP-IgE and $100 \mu \mathrm{M}$ isolated compounds for $30 \mathrm{~min}$ and subsequently stimulated them with $0.1 \mu \mathrm{g} \mathrm{mL}^{-1}$ DNP-BSA for $24 \mathrm{~h}$. Compounds 1-6 and 9 considerably inhibited TNF- $\alpha$ expression (Fig. 5). In particular, compounds 2 and 9 suppressed TNF$\alpha$ expression by up to $55.9 \%$ and $68.1 \%$, respectively. Thus, the present study determined the constituents responsible for the antiallergic effects of Xin-Yi.

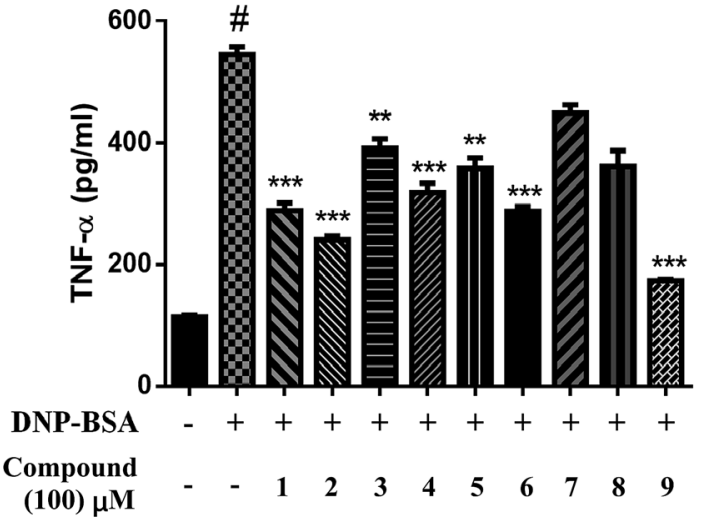

Fig. 5 Effects of isolated compounds on TNF- $\alpha$ release.

On the basis of the antiallergic effects of compounds 1-6 and 9, we demonstrated the differences in the effects of the main active Frs. E5 and E6. The HPLC fingerprints (Fig. 1B) revealed that Fr. E5 mainly contains compounds 1-8, and Fr. E6 mainly contains compounds 7-9. In addition, compounds 2 and 9 exerted the strongest antiallergic effects among the nine compounds. Fr. E6 exerted stronger effects than did Fr. E5, because compound 9 was a main constituent in Fr. E6, and compound 2 was merely a microconstituent in Fr. E5. The agreement of results on the antiallergic effects between the fractions and purified compounds illustrates the feasibility of our bioassay-guided isolation procedure. Bisepoxylignans are present in large quantities (total content of compounds 3-5, 8, and 9 up to $5 \%$ ) in Xin-Yi, ${ }^{24}$ indicating that they are the main bioactive constituents responsible for Xin-Yi's antiallergic
A

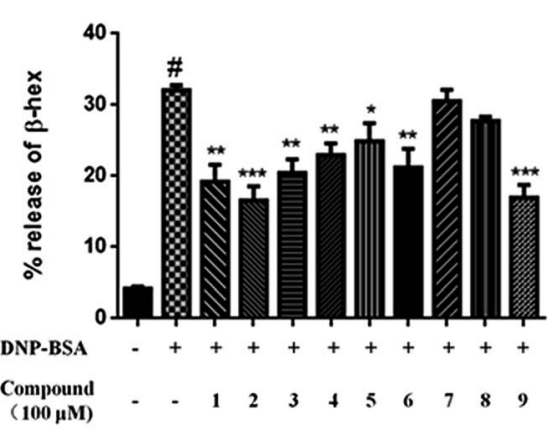

B

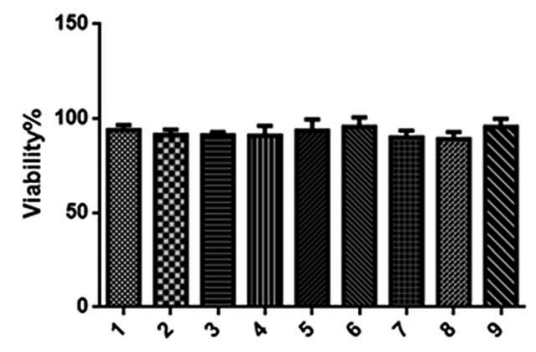

C

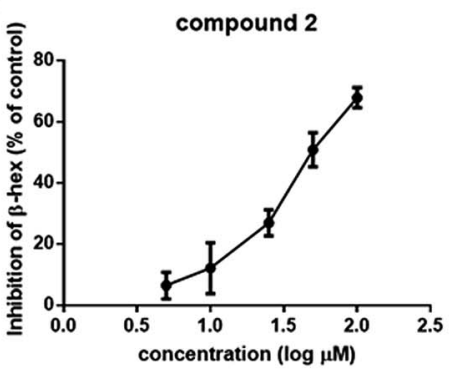

compound 9

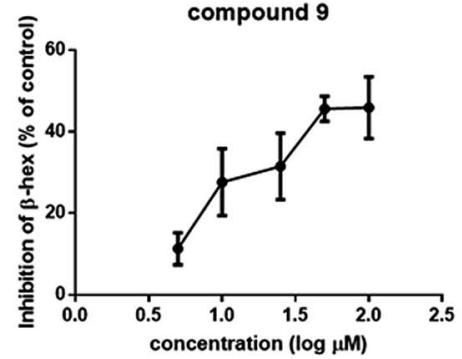

Fig. 4 Effects of isolated compounds on degranulation and cell viability. (A) BMMCs were treated with $0.5 \mu \mathrm{mL} \mathrm{L}^{-1}$ anti-DNP-lgE $24 \mathrm{~h}$, and various compounds $\left(100 \mu \mathrm{mol} \mathrm{mL} \mathrm{L}^{-1}\right.$ ) for $30 \mathrm{~min}$, then $0.1 \mu \mathrm{g} \mathrm{mL} \mathrm{L}^{-1} \mathrm{DNP}$-BSA for $30 \mathrm{~min}$. (B) BMMCs were treated with various compounds (100 $\mu \mathrm{mol} \mathrm{mL}^{-1}$ ) for $24 \mathrm{~h}$. Cell viability was determined using an XTT assay. (C) Effects of compounds 2 and 9 on BMMCs degranulation. 


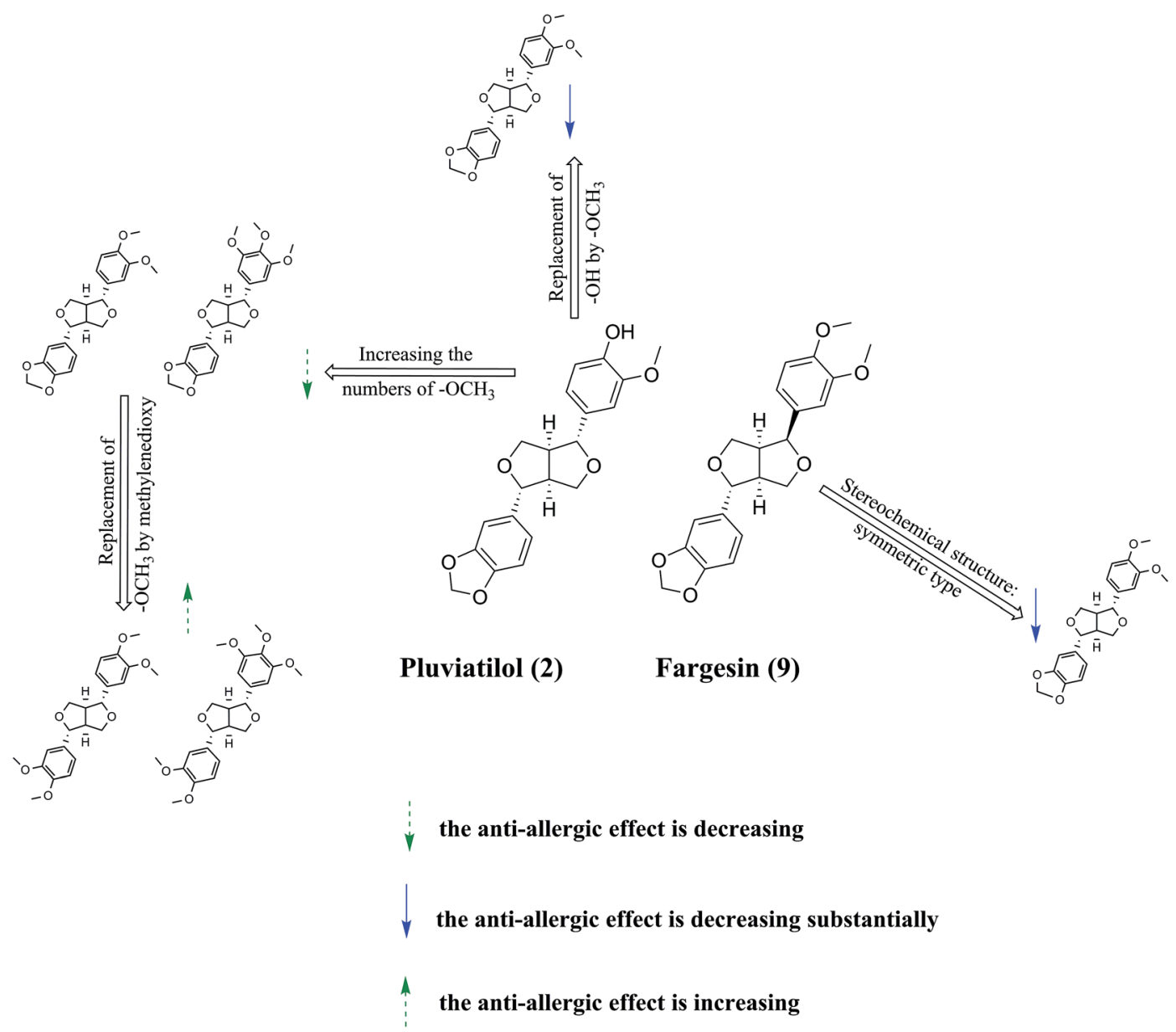

Fig. 6 The structure-activity relationships of bisepoxylignans on the anti-allergic effect.

efficacy; however, the intensity of these bisepoxylignans was moderate.

Finally, because of the similarity between the structures of compounds 1-9 and marked differences in their antiallergic effects, we can discuss the structure-activity relationship between these bisepoxylignans and antiallergic effects (Fig. 6). First, a greater number of methoxyl groups in the benzene ring was associated with a reduced antiallergic effect, as evidenced by the comparison of the antiallergic effects of compounds 2 and $\mathbf{3}$ with those of compounds $\mathbf{4 , 5}$, 7, and 8. Second, compounds 7 and 8 exerted weaker antiallergic effects than did compounds 3 and $\mathbf{4}$, indicating that the methylenedioxy group reduced the activity. Third, substitution of the hydroxyl group with a methoxyl group in the benzene ring, such as in compounds 7 and 8 , reduced the antiallergic effects compared with those of compound 2, suggesting that hydroxyl to methoxyl substitution reduces the antiallergic activity. Fourth, symmetrical bisepoxylignans, namely compounds $1,3,4,5,7$, and 8 , exerted substantially weaker antiallergic effects compared with those of the asymmetrical bisepoxylignans, namely compounds 6 and 9, indicating that the stereochemical structure of the compounds is crucial to their antiallergic activity. This finding is consistent with a previous study on the antiallergic activity of bisepoxylignans. ${ }^{15}$

\section{Conclusions}

In conclusion, nine bisepoxylignans, including one novel compound, were obtained through antiallergic bioassay-guided isolation using in vitro and in vivo models. The proposed compound (isoeudesmin) and known compounds (pluviatilol, eudesmin, magnolin, lirioresinol-B dimethyl ether, epimagnolin $\mathrm{B}$, and fargesin) obtained from Xin-Yi inhibited BMMC degranulation and TNF- $\alpha$ expression, contributing to Xin-Yi's antiallergic effect. Moreover, bisepoxylignans can be considered candidates for antiallergic agents derived from Xin-Yi.

\section{Acknowledgements}

This work was supported by the Excellent Academic Leaders Program of Shanghai (16XD1403500), the Eastern Scholar Tracking Program of Shanghai Municipal Education Commission (2012-90), the National Natural Science Foundation of China (81673570, 81261120567), and the program of Shanghai E-Research Institute of Bioactive Constituents in Traditional Chinese Medicine. 


\section{References}

1 D. L. Fu, The plant resources and new taxa and cultivars of yulania spach, The Doctoral Dissertation of Central South Forestry University. 2001, vol. 2, p. 88.

2 Y. H. Wang, F. Ye and X. H. Zhang, China Med. Her., 2012, 16, 12-14.

3 The Pharmacopoeia Commission of People's Republic of China, Pharmacopoeia of the People's Republic of China, Chemical Industry Press, Beijing, China, 2010, p. 169.

4 H. L. Wang, Z. H. Li and Y. T. Xu, Chin. Tradit. Herb. Drugs, 2015, 46, 1542-1555.

5 H. Wei, R. S. Zhang, Z. X. Si and Y. F. Zhou, Chin. J. Exp. Tradit. Med. Formulae, 1997, 3, 21-23.

6 T. Ji and L. Y. Wang, China Pharm., 2010, 19, 27-28.

7 D. H. Deng, X. H. Shen and W. R. Zhu, Chin. J. Tradit. Med. Sci. Technol., 2007, 14, 318-319.

8 J. Jiang, X. S. Fan, N. Shang and Y. C. Liu, Journal of Nanjing TCM University, 2002, 18, 333-334.

9 Q. Song and N. H. Fischer, J. Mex. Chem. Soc., 1999, 43, 211218.

10 Y. Shen, C. G. Li, S. F. Zhou, E. C. K. Pang, D. F Story and C. C. Xue, Curr. Med. Chem., 2008, 15, 1616-1627.

11 G. P. Han and H. F. Zhou, Journal of Shanxi Normal University, 2005, 6, 142-144.

12 H. S. Chae, O. H. Kang, Y. C. Oh, J. G. Choi and J. H. Keum, Immunopharmacol. Immunotoxicol., 2011, 33, 709-771.
13 T. C. Moon, C. S. Seo, K. Haa, J. C. Kim, N. K. Hwang, T. G. Hong, J. H. Kim, D. H. Kim, J. K. Son and H. W. Chang, Arch. Pharmacal Res., 2008, 31, 606-610.

14 S. S. Hong, W. Jeong, J. K. Kim, J. G. Kwon, J. Y. Lee, E. K. Ahn, J. Oh, D. W. Seo and S. Oh, Fitoterapia, 2014, 99, 347-351.

15 H. G. Choi, Y. H. Choi, J. H. Kim, H. H. Kim, S. H. Kim, J. A. H. Kim, S. M. Lee, M. Na and S. H. Lee, Arch. Pharmacal Res., 2014, 37, 467-472.

16 R. Sun, X. L. Qian and L. L. Lv, J. Pharmacovigilance, 2013, 10, 71-73.

17 D. Wang, M. Zheng and Y. Qiu, J. Exp. Med., 2014, 13, 26352649.

18 T. Iida, Y. Noro and K. Ito, Phytochemistry, 1983, 22, 211-213. 19 Y. W. Seo, Biotechnol. Bioprocess Eng., 2010, 15, 400-406.

$20 \mathrm{H}$. W. Luo, Study on the chemical components and pharmacological activity of Magnolia denudate Desr, The Doctoral Dissertation of South-Central University for Nationalities, 2013.

21 Q. Guo, H. Fang and W. Su, Chin. Tradit. Herb. Drugs, 2004, 35, 849-852.

22 T. J. Schmidt, S. Hemmati, E. Fuss and A. W. Alfermann, Phytochem. Anal., 2006, 17, 299-311.

23 H. Greger and O. Hofer, Tetrahedron, 1980, 36, 3551-3558.

24 P. M. Yu, Z. Y. Tian and Q. T. Xu, Lishizhen Medicine and Material Medica Research, 2005, vol. 16, pp. 652-653. 